\title{
Organized Crime in Albania: An Unconventional Security Threat
}

\section{Eno Trimcev ${ }^{1}$}

The end of the Cold War brought about a period of insecurity throughout South Eastern Europe (SEE). The quick and unexpected collapse of communist regimes brought to the surface a long list of new challenges that the societies of South Eastern Europe were ill equipped to deal with. Poverty, the absence of the rule of law, weak judicial systems and, in some places, open warfare and the collapse of community ties opened up plenty of opportunities for the growth and consolidation of organized crime. This essay will look at organized crime in Albania, one of the crucial links in a chain of Balkan states that are having a difficult time coping with the problem. However, it is not directly concerned with evidence of or reasons for the existence of organized crime in Albania. Rather, it will investigate the organized crime phenomenon from a security perspective.

Traditionally, security threats in Albania have been viewed in terms of "hard" security. Political actors on the Albanian scene still define their security problematic in terms of ethnic, religious, and cultural cleavages within the state, or security threats from neighboring states or ethnic groups. ${ }^{2}$ While these threats continue to be present, it has become necessary to reevaluate the definition of the security problematic in order to include organized crime. The strengthening of organized crime groups in Albania has increased the possibility of a permanent distortion of the local political system. With regard to Albania, the present definition of the security dilemma is particularly troubling. A cursory look at post-Cold War developments in Albania shows that Albanian security has not been undermined so much by hard security threats but rather by "soft" security threats. The weakness of state institutions and the entrenchment of non-democratic norms within the democratic polity have opened the way for serious security threats to Albanian citizens in the long term. ${ }^{3}$ Moreover, the lack of awareness on the part of local

\footnotetext{
${ }^{1}$ Eno Trimcev is a Researcher at the Albanian Institute for International Studies (AIIS), Tirana, Albania.

${ }^{2}$ Security Strategy of the Republic of Albania, Law number 8572, 27.01.2000. While organized crime is mentioned as a security threat, it is lumped together with terrorism, westward migration, public misinformation, and the environment. The Security Strategy mentions the growing professionalism and strength of criminal groups in Albania, without differentiating between "crime groups" and "organized crime groups." Hence, the fight against crime is seen simply in terms of strengthening those state institutions that are directly concerned with the fight against crime, such as police and the judiciary, while there is no discussion of the danger of state capture.

${ }^{3}$ See Blendi Kajsiu, Aldo Bumçi, Albert Rakipi, "Albania-A Weak Democracy, A Weak State," AIIS Report 2002, in The Inflexibility Trap: Frustrated Societies, Weak States and Democracy (Sofia: Centre for Liberal Strategies and Institute for Market Economics, 2003).
} 


\section{THE QUARTERLY JOURNAL}

and international actors of the ability of organized crime groups to penetrate the Albanian state- the so-called state capture process-means that the basic tools to combat this dangerous phenomenon are not being put in place.

\section{Growth of Organized Crime: The Social and Political Climate}

In order to support the thesis that organized crime must be viewed as a security threat that cannot be dealt with simply by strengthening policing and judicial institutions, we must look at the environment in which organized crime has evolved in Albania. In a famous 1979 article, Jeane Kirkpatrick analyzed the distinctions between authoritarian regimes of the Right and totalitarian regimes of the Left. While the former "leave in place existing allocations of wealth, power, [and] status" and "worship traditional gods and observe traditional taboos," radical totalitarianisms of the Left seek to "claim jurisdiction over the whole of society" and violate "internalized values and habits."

Albania entered the post-Cold War era burdened with the baggage of forty-five years of the most repressive totalitarian regime in Europe. In order to understand the weaknesses inherent in Albanian society today, weaknesses that range from weak state institutions to the erosion of the basic norms and values that make up organized community life, we have to investigate the dynamics of social and political life in communist Albania, especially as it represents the longest period of continuity in the existence of independent Albania.

While it is true that from an outsider's perspective the Albanian communist state did exhibit features of a strong state (strong, palpable state presence from the center to the periphery, state penetration in society, citizens' observation of state laws, and some improvement in the delivery of public services), it is also true that state-exercised violence was the primary reason for its "strength." ${ }^{5}$ Direct or indirect, physical, moral, or psychological, violence was sanctioned by constitutional law, and if the constitutionally permissible degree of repression and terror was not enough, the arbitrary use of power was used by the authorities to carry out their will. ${ }^{6}$

The complete isolation of the country, its extreme economic backwardness, and the absence of cultural and scientific opportunities that were inherited by post-Cold War Albania have been well documented, and there is no need to look at them in detail. However, what is of importance here is the social engineering project in which the Albanian regime engaged and which, in turn, destroyed many of the age-old moral values and norms that provide the basis for community life. The regime tried to build a new type of citizen, which official propaganda named

\footnotetext{
${ }^{4}$ Jeane Kirkpatrick, "Dictatorships and Double Standards," Commentary 68 (November 1979): $34-45$.

${ }^{5}$ Albert Rakipi, "Weak States and International Institutions," Ph.D. Diss., NATO Defense College, Rome, 2002.

${ }^{6}$ J. John Hall, “The Return of the State," at http://www.ssrc.orgsept11/essays/hall.
} 
"the New Man" and which is not very different from the Homo Sovieticus that many Cold War academics are familiar with. What was different about the Albanian New Man, however, was the degree of ferocity with which the regime strove to bring about this new reality. Religion was outlawed in 1967, and the 1974 Constitution declared Albania the first atheist state in the world. The New Man was supposed to be free of religious superstitions, material or carnal desires, and all other 'vices' of the capitalist world. ${ }^{7}$

Through sheer terror, the regime slowly but surely undermined the moral principles that had been built by tradition, national pride, and self-respect. Communist propaganda extolled the creation of a Communist gemeinschaft that was supposed to be based on selflessness and a willingness to sacrifice one's interests for the greater good of the community. However, in reality the threads that bound individuals together were the result of terror and fear. Once the regime was swept away due to its economic inefficiency and political inflexibility, the idea of community was swept away with it. Ferdinand Toennies drew the distinction between local community, or gemeinschaft, and the larger society, or gesellschaft. He saw the bonds of local community as being stronger, since they were based on kinship, locality, and a shared culture. Gesellschaft, on the other hand, was more impersonal and goal-oriented, circumscribed by contractual relationships. ${ }^{8}$ In the case of Albania, the state sacrificed the pre-World War II gemeinschaft in the name of a new ideology, which failed to replace it with its own self-sustaining bonds.

Today, modern Albania finds itself in the peculiar situation of having imported a democratic system based on the principles of political rights and freedoms and a market economy without being able to create the necessary gesellschaft in which the new polity can function. Given its historic political and economic backwardness and its relatively recent communist past, Albanian society has been unable to create the necessary values conducive to a well-functioning democracy. On the other hand, the assumption that a "top-down" approach to the establishment of the rule of law would prove effective has not been vindicated. Consistent enforcement of the law remains hampered by serious deficiencies in the judicial system. ${ }^{9}$ Since Albanian society lacks the values and the efficient institutional arrangements to combat organized crime, state capture has become a real danger that may result in a long-term distortion of the Albanian political system.

\section{The Current Situation}

Organized crime in Albania today has become closely interconnected with politics. A number of publications in the local and international press have docu-

\footnotetext{
${ }^{7}$ Kajsiu, et al., "Albania—A Weak Democracy."

8 "Community and Technology, Classic Ways of Looking at Community," http://www.sccs.swarthmore.edu/users/02/allan/community_technology/classic_comm.html.

${ }^{9}$ Commission of the European Communities, "Albania: Stabilisation and Association Report 2003," Commission Staff Working Paper, Brussels, 26 March 2003, 2.
} 


\section{THE QUARTERLY JOURNAL}

mented that some of the smuggling channels have functioned as government-run businesses. ${ }^{10}$ However, the real focus of this article is not to interpret organized crime in cultural terms, i.e., in terms of weak institutional environments, communist legacies, and so on. Neither is it to give evidence of the existence of organized crime and the economic wasteland that provides the fertile soil for its growth and consolidation. My thesis states that organized crime is permanently deforming the political structure of the Albanian democratic polity. Given the dangers posed by this deformation to the future of Albania, and many other countries in the region, it has become imperative that regional and international actors enlarge their focus in the war against organized crime.

I will use Ivan Krastev's model in order to analyze the level of penetration of organized crime into Albanian politics. ${ }^{11}$ While the organized crime epidemic is closely related to Albania's communist legacy, its economic backwardness, and the quality of its legal system, the international community and local actors have long been well aware of these causes, and steps are being taken to help reshape the structural tools needed to fight organized crime. Although actual results have been almost impalpable, it is safe to state that a focus on these issues does exist. On the other hand, there has been little effort to explain the increasingly well-established links between organized crime revenues and the increasing cost of politics in Albania and the Balkans more generally. ${ }^{12}$ In the early years of transition, there was public resentment over the extreme levels of political confrontation. However, persistent accusations of corruption were absent. As the struggle against communism abated and politics lost its attractive dynamic as an idealistic exertion for the public good, there was a resultant diminishment in interest in politics and an outflow of "militants," or extremely committed individuals, from the political parties. The present 'reduction' of politics from an impassioned struggle to a quarrel over minor differences in such a short period of time has brought about a relative alienation of the electorate from local political parties and growing numbers of voters absent from the electoral process. The absence of alternative institutions for citizen participation in decision-making and governance has made this problem even more serious for Albania.

This situation has opened the door for organized crime's penetration into politics. The massive withdrawal of motivated citizens from political activities has suddenly made political communication much more expensive. In 1991, enthusiastic young people were actively involved in political demonstrations and other political activities. Now, youngsters have become alienated from the political process. In order to have their posters disseminated, and their political meetings well

\footnotetext{
${ }^{10}$ Ivan Krastev, The Inflexibility Trap: Frustrated Societies, Weak States and Democracy (Bratislava: United Nations Development Programme, 2002), 18.

${ }^{11}$ Ibid., 6-23.

${ }^{12}$ Ibid., 21.
} 
attended for media purposes, political parties have to pay. ${ }^{13}$ In 1991, with citizens on the streets eager to participate in the political process, it was easy and cheap for politicians to get their message across. Today they have to pay for expensive media commercials and rock-concert type electoral meetings. The result is that parties are selling their influence over the decision-making process to the highest bidder. According to Krastev, the increased cost of politics and the effort to pay the price have four major consequences. First, people become even more disgusted with politics, so the cost of politics goes up. Second, the new way of conducting politics leads to the promotion of new politicians, who Della Porta calls "business politicians." Third, the increased price of politics undermines the morality of individual politicians within political parties. Those who start taking money for the party through unofficial channels find it a great deal easier from a moral standpoint to start taking money for themselves. Fourth, political parties create a class of donors close to them. A mutually advantageous relationship is established whereupon a business gives funds to a political party in exchange for favorable policy or administrative decisions. One of the main tools with which political parties ensure their revenues is the privatization process. Privatization is no longer about what to sell, but who to sell to. Only recently, allegations sprung up quite openly that the Albanian government was buying the media through companies that are considered "friendly" to the ruling Socialist Party. ${ }^{14}$

\section{A New Approach to Organized Crime}

Richard Rose has shown that the real danger to democracy does not come from the poor or from former members of the Communist Party. Instead, it comes from those that are convinced that their party is wholly corrupt. ${ }^{15}$ While this nightmare scenario need not be fulfilled in Albania, it is painfully obvious that the modus vivendi that has been reached between state and political institutions and organized crime is causing a permanent deformation of the democratic system. It is essential to grasp that a transformation in the process of governance, be it negative or positive, that persists over time will eventually solidify and become the norm. While political rhetoric pays lip service to the fight against organized crime, actual results have been meager at best.

As a matter of fact, there have been a number of initiatives undertaken to combat organized crime in Albania, but their outcomes have shown few tangible results. An international anti-drug trafficking center was set up in the southern city

\footnotetext{
${ }^{13}$ Drini Skënderi and Anisa Tabaku, interview with author. Many young Albanians are paid to become 'members' of political parties and to attend their meetings or distribute their literature.

${ }^{14}$ Interview with Fatos Lubonja on KLAN TV, "Opinion,” 13 April 2003. He accused the owner of one of the main independent newspapers, Shekulli, of profiting through illegal auctions of public property. The government uses paid job advertisements and commercials to fund media close to it and to financially disadvantage those media that do not support its point of view.

${ }^{15}$ Richard Rose, “A Diverging Europe,” Journal of Democracy 12:1 (2001): 93 - 106.
} 


\section{THE QUARTERLY JOURNAL}

of Vlore to be jointly run with Italy, Greece, and Germany. ${ }^{16}$ However, the center's work has been marred by allegations of idleness that reached a fever pitch when the German officer assigned to the center resigned because the center had been de facto by-passed by local police structures and had become redundant. Another well-publicized action was Operation "Labor," which aimed to interrupt the flow of human and drug smuggling to Italy. Officially, the operation ended successfully, with the Prime Minister symbolically burning a number of confiscated speedboats at a media event. However, of the seventeen people arrested in the operation, today only one, a simple policeman, is still in prison. The others were allowed to go free by the courts.

Given the fact that, at present, the political dynamic in Albania is such that the lines between organized crime and the political class have become very blurry indeed, a new approach to this fight is needed. The measures that have been taken by the international community in cooperation with local actors up to this point, while commendable and necessary, must be improved upon. Some measures have been undertaken in regard to the institutionalization of the fight against organized crime. With international help, those state institutions that are designed to directly combat organized crime are being strengthened, and regional cooperation is being reinforced. Thus, there seems to be some awareness, at least on the level of political rhetoric, of the need to fight organized crime, and there appears to be increasing political will to at least project an image of fighting this phenomenon head-on. While results have been poor, work must continue to strengthen those state institutions that are confronting organized crime. Some of the practical areas where tangible progress must be made are:

- Strengthening the institutional structures necessary for implementing the Law on Money Laundering.

- Establishing a fully financed and well-publicized witness protection system.

- Making serious efforts to control border crossings. ${ }^{17}$

- Beginning prosecutions of corrupt judges and prosecutors.

- Enhancing cooperation between state police, the judicial police, and the prosecutor's office. ${ }^{18}$

Nevertheless, the debate on organized crime in Albania lacks a very important dimension. While anecdotal evidence abounds, there exist no models or studies

\footnotetext{
${ }^{16}$ International Crisis Group, "Albania: State of the Nation 2003," 11 March 2003, http://www.intlcrisis-group.org.

${ }^{17}$ Ibid.

${ }^{18}$ Commission Staff Working Paper, "Albania: Stabilisation and Association Report 2003," Commission of the European Communities, Brussels, 26 March 2003.
} 
to measure the extent of state capture by organized crime syndicates. As a matter of fact, not only does organized crime distort the Albanian political system, it also imposes conditions on the systemic structure of the state, and therefore it makes the implementation of structural reforms very difficult. For example, interviews with Albanian political leaders by researchers from the Albanian Institute of International Studies on electoral system reform in local government elections produced valuable insights on the way organized crime limits the available choices in electoral reform discussions. At present, municipal councilors in Albania are elected through a proportional system. Different analysts have raised concerns about the lack of representation in municipal councils and are advocating a majoritarian system. However, given the strong presence of organized crime in Albania, there exists a justifiable fear that such a system would make it easier for criminal structures to get their representatives elected to municipal councils. Yet, this argument would only be valid if we assume that organized crime has not already captured various Albanian political parties, which is a very daring assumption indeed. While the present manifestation of the war on organized crime may strengthen the state in the short term, it also has the unfortunate side effect of consolidating criminal structures within the hierarchy of power. In a country with a democratic system of governance where the relationship between citizens and their elected representatives is as weak as it is in Albania, the alienation of voters from the political process is considerably increased by perceptions of corruption and state capture. In turn, this increases the cost of politics and, according to Krastev's model, it facilitates even further the penetration of organized crime into the body politic.

Hence, investing time, effort, and money in the institutions that are directly concerned with the fight against organized crime ought to be only part of the general effort to cleanse our political and social lives of this phenomenon. The time has come to enlarge the concept of security in order to include organized crime as one of the security threats facing Albanian society. While traditional security threats remain relevant, it has become obvious that the old definition of "security" is becoming obsolete. Transitional societies, such as the societies of South Eastern Europe, are in the midst of the state-building process. If that process becomes deformed by the presence of organized crime, it will be very difficult to undo the damage. In Albania, little if anything is being done to create favorable socioeconomic conditions that may help arrest the growth of organized crime. Policy formulation and implementation does not factor in the clear and present danger of "state capture" as one of the greatest threats facing Balkan societies today. Often, local elites speak in terms of "us" (the law-makers and law-enforcers) against "them" (the law-breakers) while, in fact, the lines between the two groups seem to be a great deal blurrier. In Albania, the lack of long-term development policies coupled with a lack of awareness about the deformation that organized crime will quite probably cause to the local political system make victory in the fight against 
organized crime quite questionable in the long term. Given the present situation, it will be no surprise if the state is captured by organized crime through free and fair elections. We run the danger of having the appearance of a democratic state, while the internal structure is controlled by criminal organizations. The complete absence of transparency regarding the electoral funds of Albanian political parties cannot help but raise questions about their ability to clearly position themselves on the opposite side of the barricades in the war on crime. 


\section{Bibliography}

Albania: Stabilisation and Association Report 2003 In Commission Staff Working Paper. Brussels: Commission of the European Communities, 2003.

Albania: Stabilisation and Association Report 2003 In Commission Staff Working Paper. Brussels: Commission of the European Communities, 2003.

Albania: State of the Nation 2003. International Crisis Group, 2003.

Kajsiu, Blendi, Aldo Bumçi, and Albert Rakipi. AlbaniaA Weak Democracy, A Weak State In AIIS Report 2002, The In exibility Trap: Frustrated Societies, Weak States and Democracy. Sofia: Centre for Liberal Strategies and Institute for Market Economics, 2003.

Kirkpatrick, Jeane. "Dictatorships and Double Standards." Commentary 6868 (1979): 34-45

Krastev, Ivan. The In exibility Trap: Frustrated Societies, Weak States and Democracy. Bratislava: United Nations Development Programme, 2002.

Rakipi, Albert. Weak States and International Institutions In NATO Defense College. Vol. Ph.D. Diss. Rome, 2002.

Rose, Richard. "A Diverging Europe."Journal of Democracy 12, no. 1 (2001): $93-$ 106.

Security Strategy of the Republic of Albania., 2000. 